\title{
„Fabrica ecclesiae kalinoviensis” w II połowie XVIII wieku i na początku XIX wieku
}

\section{“FABRICA ECCLESIAE KALINOVIENSIS" FROM THE SECOND HALF OF THE 18TH CENTURY TO THE BEGINNING OF THE 19TH CENTURY}

The Catholic church in Kalinówka Kościelna, Poland, belongs to one of the oldest parishes in the Archdiocese of Białystok, which used to be a part of the (Arch)diocese of Vilnius. The parish was established in 1511 when Mikołaj Radziwiłł built a church that stood until the Swedish Deluge. The current sanctuary is made of larch wood and is the third of three churches erected by Fr. A. Świerzbiński. While the precise year and circumstances in which the sanctuary was built are unknown, records show that it was consecrated in 1777 by Fr. A. Świerzbiński's successor, Fr. W. Klimaszewski, who also oversaw a series of renovations and changes to the rectory and the pastors' homestead. Fr. Szymon Szyszko founded the new cemetery, which is located outside of Kalinówka, in 1811. This article includes a copy of the document that authorized the establishment of the cemetery as well as many other original sources pertaining to the parish in Kalinówka Kościelna and the priests who have served there.

Key words: parish in Kalinówka Kościelna, church construction, church consecration, fire in the rectory, establishment of a cemetery, parish records, pastors, komendarze, notes.

W dotychczasowych opracowaniach dotyczących dziejów parafii Kalinówka Kościelna różnie były przedstawiane kwestie związane z budową obecnego kościoła, jej związku z pożarem plebanii w 1761 
roku, konsekracją nowej świątyni oraz sprawa założenia obecnego cmentarza grzebalnego. W niniejszym artykule pragnę przedstawić uporządkowane spojrzenie na te zagadnienia, wykorzystując przy tym dostępne materiały źródłowe, w tym również księgi metrykalne parafii Kalinówka. Księgi te zawierają interesujące zapisy, które uzupełniają naszą wiedzę o ważnych dla parafii wydarzeniach oraz dostarczają cennych informacji o posługujących w niej duszpasterzach.

\section{Budowa kościoła, plebanii i zabudowań gospodarczych}

Pierwszy kościół w Kalinówce, który zbudował fundator parafii Mikołaj Radziwiłł ku czci Matki naszego Zbawiciela Dziewicy Maryi, szczególnie Jej Niepokalanego Poczęcia i Jej matki św. Anny oraz Świętych Mikołaja i Leonarda oraz Wszystkich Świętych około roku 1511, został prawdopodobnie zniszczony w czasie wojen z Moskwą i ze Szwedami w połowie XVII wieku. Drugi kościół, odbudowany przez proboszcza ks. Jana Pawińskiego, przetrwał na pewno do drugiej połowy XVIII wieku' ${ }^{1}$ Trzecią świątynię, która nadal służy wiernym parafii Kalinówka, wybudował kanonik inflancki Adam Świerzbiński.

Ksiądz A. Świerzbiński objął parafię w Kalinówce wiosną lub latem 1753 roku, przechodząc tutaj z Juchnowca ${ }^{2}$. Zanim ostatecznie osiadł w Kalinówce, przez jakiś czas, być może do marca 1754 roku, proboszczował jednocześnie w obu parafiach ${ }^{3}$. Na urzędzie proboszcza kalinowskiego poprzednikami ks. Świerzbińskiego byli ks. Mateusz Antoni Perkowski (1738-1749) i ks. Jan Antoni Czaczkowski (17491753). W duszpasterstwie pomagali im komendarze, m.in. ks. Marcin

History of the Church

Giełczyński i Jan Krzysztof Sulimowski, zaliczani w niektórych opracowaniach do proboszczów kalinowskich ${ }^{4}$. Pierwszy sprawował funkcję komendarza do roku 1745, drugi w latach 1751-1760 .

$1 \quad$ T.Krahel,Zarys dziejów parafii w Kalinówce Kościelnej, [w:]Parafia w Kalinówce Kościelnej 1511-2011. Pięć wieków historii, A. Szot red., Białystok-Kalinówka Kościelna 2011, s. 32-33.

2 W aktach chrzcielnych parafii kalinowskiej z kwietnia 1753 r.ks. A. Świerzbiński widnieje jako proboszcz juchnowiecki i zarazem commendarius officialis kalinovien[sis], natomiast poczynając od sierpnia tego roku tytułuje się wyłącznie proboszczem lub prepozytem kalinowskim.

3 Por. S. Niewiński, Juchnowiec. Dzieje parafii, Juchnowiec Kościelny 2017, s. 198.

4 Por. Wykaz księży proboszczów parafii Kalinówka Kościelna, [w:] Parafia w Kalinówce Kościelnej 1511-2011. Pięć wieków historii, A. Szot red., Białystok Kalinówka Kościelna 2011, s. 431-432.

5 W księgach metrycznych z tego okresu ty tułują się oni wyłącznie komendarzami kalinowskimi. 
Na podstawie zachowanych źródeł nie można precyzyjnie określić czasu i okoliczności budowy obecnego kościoła. W niektórych publikacjach podaje się rok $1774^{6}$. Opinia ta opiera się zapewne na dwóch zapisach poczynionych przez ks. Walentego Klimaszewskiego w inwentarzu, który sporządził przy objęciu parafii w tym właśnie roku - pierwszy informuje, że „kościół pod tytułem św. Anny de novo ufundowany przez śp. ks. Świerzbińskiego per totum nowy”, w drugim wspomina, że „wszystkie budynki, jako y kościól, dzwonnica y plebania są kosztem śp. ks. Świerzbińskiego po konflagracyi erigowane y denowo fundowane" ". Inni autorzy przesuwają budowę obecnej świątyni na lata 1776-1777, łącząc ją zapewne z konsekracją kościoła, która miała miejsce 5 października $1777 \mathrm{roku}^{8}$.

Zachowane źródła archiwalne odnoszące się do parafii Kalinówka nie potwierdzają jednoznacznie tych opinii. Większość z nich, w tym także wnioski, które pojawiły się przy okazji ewidencjonowania konserwatorskiego wyposażenia wnętrza kościoła w Kalinówce (na co przed kilkunastu laty zwróciła uwagę Z. Cybulko), przemawiają za wcześniejszym powstaniem świątyni ${ }^{9}$.

W inwentarzu z 1804 roku zapisano, że obecny kościół został „wybudowany w roku 1758 dnia 19 maja przez ks. A. Świerzbińskiego"10,

${ }_{6} \quad$ Spis kościotów i duchowieństwa Archidiecezji w Biatymstoku, red. C. Potocki, Białystok 1973, s. 90; Spis kościołówi iduchowieństwa Archidiecezji w Białymstoku. Rok 1988, red. C. Potocki, Białystok 1988, s. 167; Spis kościołów i duchowieństwa Archidiecezji Białostockiej. Rok 1998, red. A. Skreczko, T. Krahel, S. Hołodok, L. Kupniewska, K. A. Jabłoński, Białystok 1998, s. 212.

7 Archiwum Archidiecezjalne w Białymstoku (dalej: AAB), Inventarium Ecclesiae Kalinoviensis Post Fata Illustris Domini Adami Swierzbinski Canonici Livoniensis Parochi Kalinoviensis Conscriptum ac Illustri Domino Valentino Klimaszewski circa introductionem per me infra scriptum die 24 maj 1774 Traditum, s. nn.

8 Zob. Stownik geograficzny Królestwa Polskiego i innych krajów słowiańskich, red. F. Sulimierski, B. Chlebowski, Wł. Walewski, t. 3, Warszawa 1882, s. 682; J. Kurczewski, Biskupstwo wileńskie, Wilno 1912, s. 241; M. Wrzeszcz, Kalinówka Kościelna, [w:] Encyklopedia Katolicka, t. 8, Lublin 2000, kol. 390; Spis kościołów i duchowieństwa Archidiecezji Białostockiej. 2008, red. A. Skreczko, T. Krahel, A. Kakareko, R. Balunowski, T. Powichrowski, Z. Łaszcz, Białystok 2008, s. 240; Schematyzm Archidiecezji Białostockiej 2014, red. J. Grzegorczyk, J. Jabłoński, A.Kakareko,Z. Łaszcz (Opracowania historii Archidiecezji i parafii:T.Kasabuła, M. Wróbel), Białystok 2014, s. 294. A. Kalisz datuje rozpoczęcie budowy kościoła na rok 1768. Idem, Kalinówka Kościelna. Zespót kościoła parafialnego pw. św. Anny, Dokumentacja historyczno-architektoniczna, Pracownia Konserwacji Zabytków, O/Białystok 1980, s. 10.

Zob. Z. Cybulko, Kilka uwag do dziejów kościoła kalinowskiego, „Biuletyn Konserwatorski Województwa Podlaskiego" 1999, z. 5, s. 161-171.

10 Archiwum Diecezjalne w Łomży (dalej ADŁ), nr 183: Inwentarz czyli Opis Stanu Kościoła Kalinowskiego w Dekanacie Knyszyńskim ze wszystkiemi 
natomiast wizytacja generalna z 1828 roku oraz kronika kościoła kalinowskiego z 1849 roku informują, że świątynię pobudowano w roku $1768^{11}$. Pierwszy zapis pochodzi od ks. W. Klimaszewskiego, który był bezpośrednim następcą budowniczego kościoła ks. Świerzbińskiego i wiedzę na temat budowy posiadał niejako „z pierwszej ręki”. Jeśli nie doszło do pomyłki w zapisie, mielibyśmy dowód, że nowy kościół został zbudowany jeszcze przed pożarem plebanii i zabudowań parafialnych, który miał miejsce 17 sierpnia 1761 roku.

Argumentów za takim przebiegiem wydarzeń dostarcza analiza treści regestru dokumentów funduszu kościoła kalinowskiego, który „po konflagracie plebanii” w 1761 roku sporządził ks. Świerzbiński. Jak zauważył ks. T. Krahel, regestr odnosi się do szkód wynikłych na skutek pożaru plebanii, natomiast nic nie wspomina się w nim o pożarze samego kościoła. Wzmiankuje się tylko, że w ogniu spłonęły wykazy wydatków poczynionych na nowy kościół i nową dzwonnicę: „wszystkie księgi moje regestra, w których expensa były wyrażone tak na kościół nowy jako też na dzwonnicę nowo"12.

Informację o tym, że kościół spalił się razem z plebanią podaje tylko ks. Szymon Szyszko w piśmie do archidiakona białostockiego ks. Kazimierza Kubeszowskiego z 27 stycznia 1819 roku ${ }^{13}$. Jest ona relatywnie późna i może być nieprecyzyjna na skutek niewłaściwej interpretacji

History of the Church prznależytościami podtug Erekcyow Fundoszowych spisany $w R^{\underline{u}} 1804$.

11 Litewskie Państwowe Archiwum Historyczne w Wilnie (dalej LPAH), Wizyta Jeneralna Kościoła Parafialnego Kalinowskiego... uczyniona 1828 Roku Miesiaca Listopada (f. 694, op. 1, d. 3747): „Kościół parafialny we wsi Kalinówce... przez Księdza Świerzbińskiego proboszcza z drzewa kostkowego w roku 1768 pobudowany", k. 1; Kronika Kościoła Parafialnego w Kalinówce położonego w Dyecezyi Wileńskiej, Guberni Grodzieńskiej, Powiecie Białostockim, Dekanacie Białostockim 1849. W 1851 roku 30 oktobra podana do Dziekana, [za:] G. Ryżewski, Kronika kościoła w Kalinówce z 1851 r. Aneks, [w:] Parafia w Kalinówce Kościelnej 1511-2011. Pięć wieków historii, A. Szot red.,, Białystok - Kalinówka Kościelna 2011, s. 177.

12 Zob. T. Krahel, Zarys dziejów parafii w Kalinówce Kościelnej, s. 34, 42; Por. Z. Cybulko, Wartości zabytkowe kościoła parafialnego w Kalinówce Kościelnej, [w:] Parafia w Kalinówce Kościelnej 1511-2011. Pięć wieków historii, A. Szot red., Białystok - Kalinówka Kościelna 2011, przypis 3, s. 109..

13 Zob. AAB, Akta kościoła kalinowskiego od roku 1817º dla dobra przez ks. Szyszke erygowane $i$ utrzymane, s. nn.: „Którego to funduszu w oryginale złożyć nie mogę, lecz w księdze oprawnej naydawniejszej wraz z innemi Dokumentami w Aktach Goniądzkich... oblatowanemi, a późniey wyjętemi Extraktami przez śp. Xędza Swierzbienskiego Proboszcza Kalinowskiego... dołączam, a to dlatego, że sam Kościół wraz z całym zabudowaniem Plebanii zpalił się a razem wszystkie Przywileje, Fundusze i inne Dokumenta z dymem do nieba uniosły się Roku 1761 dnia 17 augusta". 
zapisu w regestrze z 1761 roku, zwraca bowiem uwagę w obu dokumentach podobieństwo w opisaniu poczynionych przez ogień strat: „metryki parafialne z dymem do nieba poszły” - pisze w regestrze ks. Świerzbiński, zaś ks. Szyszko w swoim liście podaje - „przywileje, fundusze i inne dokumenta z dymem do nieba uniosły się".

Pożar musiał mieć dość ograniczony zasięg. Wynika to z treści inwentarza z 1774 roku, gdzie obok nielicznych obiektów nowych lub w dobrym stanie (kościół „per totum nowy”, „dzwonnica nowa” i „plebania dobra”), wymienia się dużą liczbę zabudowań starych lub wymagających wyremontowania, np. budynek dla czeladzi, browarek, kuchnia, sklep w ogrodzie i większość domów włościańskich „na Poświętnym”14. Budynki określone w inwentarzu jako „stare” nie mogły spłonąć w pożarze, podobnie też mógł ocaleć nowo pobudowany kościół i dzwonnica.

Argumentów za tym, że pożar z 1761 roku nie zniszczył kościoła zdaniem Z. Cybulko - dostarczają wyniki wspomnianej wyżej wizytacji konserwatorskiej. Skoro ołtarz główny z uznawanym za cudowny, barokowym obrazem Matki Bożej Łaskawej, ambona, czy też rzeźby na belce tęczowej pochodziły ze starej świątyni, świątynia nie mogła spłonąć w pożarze ${ }^{15}$. Jest bowiem mało prawdopodobne - argumentuje Z. Cybulko - aby z pożogi zdołano ocalić obiekty takiej wielkości, jak np. ołtarz główny ${ }^{16}$. Nie można co prawda wykluczyć, że ołtarz i inne zachowane elementy wystroju wnętrza pochodziły z innego kościoła, ale nie znajduje to potwierdzenia w źródłach ${ }^{17}$.

Ponadto w inwentarzu z 1774 roku wiele z elementów wyposażenia świątyni określa się jako wiekowe lub wymagające naprawy: „trzy ołtarzem adornacyi zwyczajnej potrzebują - bo choć niektóre są malowane i pozłacane, ale dawne”, „baptisterium stare”, ,,ambona stara”, „ławki do siedzenia parafianów nadruinowane”, „w zakrystii posadzka miejscami nadgniła". Podobnie oceniony został stan wielu naczyń

$14 \quad \mathrm{AAB}$, Inventarium Ecclesiae Kalinoviensis... 1774, s. nn.: „Budynek, w którym czeladź mieszka stary, za tym budynkiem od gaiu olszowego browarek stary, przy nim wotownia i chlewkow trzy matych dla ptastwa, na boku tego budynku kuchenka stara. W ogrodzie sklep stary... budynkow chłopskich pięć zgodnych jeszcze do mieszkania, a dziewięć reparacyi potrzebuja, szpital stary, karczma stara gwattownej reparacyi potrzebujaca, browar wraz z[t]wnia stary", s. nn.

15 Por. Z. Cybulko, Kilka uwag do dziejów kościoła kalinowskiego, s. 164-168.

$16 \quad$ Ibidem, s. 169.

17 Ibidem, przypis 21, s. 171; M. Wróbel, Parafia w Kalinówce Kościelnej w latach 1795-1914 w świetle działalności jej duszpasterzy, [w:] Parafia w Kalinówce Kościelnej 1511-2011. Pięć wieków historii, A. Szot red., Białystok - Kalinówka Kościelna 2011, przypis 9, s. 250. 
liturgicznych i innych sprzętów kościelnych: „łó[d]ka cynowa stara”, „puszka do hostyi blaszana stara”, ,żelazo do pieczenia opłatkow już stare”, „ampułek cynowych starych dwie”, „obrazów do noszenia w procesyi starych dwa”, „poduszek do ołtarzow starych trzy” ${ }^{18}$. Jeśli na trzy lata przed konsekracją kościoła obiekty te były już stare i wymagające renowacji, musiały pochodzić z innej starszej świątyni ${ }^{19}$.

Jak podaje regestr z 1761 roku, w pożarze plebanii spłonęły parafialne księgi metrykalne: „metryki parafii kalinowskiej tak kościoła kalinowskiego i kościoła brzozowskiego [...] z dymem do nieba poszły". Podobnie jak w innych parafiach były one prowadzone od pierwszych lat XVII stulecia: księga chrztów od 1611 roku a księga małżeństw od $1614 \mathrm{roku}^{20}$. Z ksiąg założonych przed pożarem zachowały się jedynie trzy woluminy: dwie księgi chrztów i małżeństw - pierwszą założył ks. M. A. Perkowski z zapisami chrztów z lat 1742-1764 oraz małżeństw z lat $1738-1764^{21}$, drugą założył ks. A. Świerzbiński - zawiera ona metryki chrzcielne $\mathrm{z}$ lat $1764-1788$ i małżeństw z lat $1764-1787^{22}$ oraz jedna księga zmarłych za lata 1749-1798, założona przez ks. J. A. Czaczkowskiego niebawem po objęciu przez niego parafii ${ }^{23}$.

Budowniczy kościoła ks. A. Świerzbiński nie doprowadził do konsekracji świątyni. W kwestionariuszu z 1849 roku zamieszczono wzmiankę, że w 1768 roku dokonał tylko jej poświęcenia. Być może jest to pomyłka i chodzi o rok 1758 . Według ks. T. Krahela poświęcenie kościoła należałoby łączyć z początkiem odprawiania w nim nabożeństw ${ }^{24}$.

History of the Church

18 AAB, Inventarium Ecclesiae Kalinoviensis... 1774, s. nn.

19 Zob. Z. Cybulko, Kilka uwag do dziejów kościoła kalinowskiego, s. 166.

20 Zob. W. Wróbel, Kościót parafialny w Kalinówce Kościelnej i jego wyposażenie $w$ świetle inwentarza z 1620 R. (Aneks), [w:] Parafia w Kalinówce Kościelnej 1511-2011. Pięć wieków historii, A. Szot red., Białystok - Kalinówka Kościelna 2011, s. 116, 121.

$21 \quad$ APKal, Liber Metrices Baptisatorum et Copulatorum Ecclesiae Parochialis Kalinoviensis ab 1742... 1738: Liber Metricaru'Copulatoru'Ecclesiae Kalinoviensis per me Mathaeu' Antonium Perkowski Parochum Kalinoviensem procuratus proprio Su'ptu Anno Dni 1738 Die 23. 8bris, k. 3.

22 APKal, Liber Metrices Ecclesiae Parochialis Kalinoviensis Brzozoviensisq. tam ex una Parte Baptisatorum quam ex Altera Parte Conjugatorum (...) Per me Adamum Swierzbinski Canonicum Livoniensem Kalivoviensem Brzozoviensemq. Parochum Anno Domini 1764 Die 15 Februarij Comparatus.

23 APKal, Liber Parochianorum Kalinoviensium In Domino Mortuorum et circa Ecclesiam parochialem kalinoviensem Sepultorum post obtentum Rectoratum praedictae Ecclesiae Per me Joannem Antonium Czaczkowski Kalinoviensem et Brzozoviensem modernum Parochum Anno Domini 1749. Scribi Inceptus et Comparatus.

24 Zob. T. Krahel, Zarys dziejów parafii w Kalinówce Kościelnej, s. 34. 
Ksiądz Świerzbiński zmarł w Kalinówce w 1774 roku. Zostało to odnotowane w księdze zmarłych kalinowskiej parafii przez ks. W. Klimaszewskiego:

Dnia 12 kwietnia zmarł wielebny Adam Świerzbiński proboszcz kalinowski, kanonik inflancki w wieku lat $70[77 ?]^{25}$ zaopatrzony wszystkimi sakramentami, pogrzebany przed drzwiami kościoła w samym wejściu. $\mathrm{W}$ tym beneficjum przeżył lat 23 sprawując troskę duszpasterską a także w kościele juchnowieckim troszcząc się o zbawienie dusz przeżył lat 20 i tam też przebywając przy wspaniałym kościele juchnowieckim wiele cudów wpisał ręką swoją do Księgi cudów Błogosławionej Maryi Dziewicy ${ }^{26}$.

Ksiądz Klimaszewski objął parafię w Kalinówce 15 maja 1774 roku. Pod adnotacją o śmierci ks. Świerzbińskiego zapisał:

W roku 1774 dnia 15 maja po śmierci wielce wielebnego Adama Świerzbińskiego, proboszcza kalinowskiego kanonika inflanckiego objąłem we władanie ja Walenty Klimaszewski proboszcz kalinowski, kanonik wileński wywodzący się z diecezji płockiej Ziemi Łomżyńskiej Dystryktu Zambrowskiego i parafii zambrowskiej dziedzic na Klimaszach, Jabłoni, etc. w 43 roku życia urodzony w roku $1731^{27}$.

Nowy proboszcz kontynuował prace przy świątyni i doprowadził do jej konsekracji, której w niedzielę 5 października 1777 roku dokonał biskup synopejski i sufragan łucki na okręg brzeski Jan Szyjkowski²8.

$25 \quad$ W wizytacji generalnej parafii juchnowieckiej z 1740 roku zapisano, że ks. A. Świerzbiński został ochrzczony 29 kwietnia 1689 roku. Por. S. Niewiński, Juchnowiec, s. 198.

D[ie] 12 Apr[ilis] Obiit perlustris Rverendus Adamus Świerzbiński Parophus Calinoviensis Canon[icus] Liv[oniensis] annorum aetatis 70 [77?] munitus omnibus Sacramentis sepultus ante Janua Ecclesiae in ipso aditu vixit in hoc Benefitio annis 23, [in:] cura animar[um] (atque) in Ecclesia Juchnoviensi circa History of curam animarum vixit annis 20 ibique existens circa praestatam Ecclesiam Juchnoviensem multa miracula ad Librum miraculorum B. V. Mariae conscripsit. manu sua. Liber Parochianorum Kalinoviensium In Domino Mortuorum et circa Ecclesiam parochialem Kalinoviensem Sepultorum post obtentum Rectoratum praedictae Ecclesiae Per Me Joannem Antonium Czaczkowski Kalinoviensem et Brzozoviensem Modernum Parochum Anno Domini 1749, k.19.

Anno 1774to D[ie]15ta Maj Postobitum Illustri[ssimi]Admodum Re[verendi]Adami Świerzbieński Parochi Kalinoviensis Canonici Livoni[ensis] Comprehendi in Possessionem meam Ego Valentinus Klimaszewski Parochus Kalinoviensis Cano[nicus] Vilnensis[Origine]Diecesis Plocensis. Terrae Lomzensis Districtus Zambroviensis et Parochiae Zambroviensis Heres in Klimasze, Jabton etc. annorum aetatis suae 43 natus 1731: Liber Parochianorum Kalinoviensium [...] Anno Domini 1749, k. 19.

Bp Jan Szyjkowski konsekrował także inne kościoły na terenie diecezji łuckiej i wileńskiej, m.in. w Bielsku Podlaskim, Domanowie, Ostrożanach, Pulsach i Przesmykach. Zob. J. Kurczewski, Biskupstwo wileńskie, Wilno 1912, s. 241, $243,245$. 
Wydarzenie to ks. Klimaszewski odnotował w Liber metricus copulatorum parafii kalinowskiej:

Kościół w tymże Roku Konsekrowany przez J. W. Xiędza Jana Szyjkowskiego Biskupa Synopeyskiego Die 5ta 8bris Consecrationis dies assignata Dominica $38 \mathrm{bris}^{29}$

Zapis ten został poczyniony w październiku lub listopadzie 1777 roku, czyli niebawem po uroczystości konsekracyjnej ${ }^{30} \mathrm{i}$ jest on bezpośrednim świadectwem potwierdzającym to wydarzenie. Do tej pory data konsekracji kościoła w Kalinówce była znana z inwentarza wizytacyjnego z 1804 roku, który ks. Klimaszewski sporządził pod koniec swojego życia ${ }^{31}$.

Ksiądz W. Klimaszewski troszczył się także o plebanię i pozostałe zabudowania parafialne. Pobudował pięć nowych budynków, w tym kuchnię, spichlerz oraz dokończył budowy plebanii. Na plebanii wymurował kominy i piece, a pokoje wyposażył we wszystkie potrzebne meble. Ponadto za sumę 604 zł. wyszlamował staw plebański, rów do stawu i przed kołem młyńskim oraz wyremontował młyn. Informację o tych pracach zamieścił w księdze małżeństw parafii kalinowskiej:

Roku 1777 Stawek slamowany Przeze mnie Xiędza Klimaszewskiego Proboszcza Kalinowskiego Kan. Wilen. Za Konczony Die 24 9bris od Którego Zapłaciłem Złotych 404. Tudziesz młynek reparowałem Ze wszytkiem Zapłaciłem złot[ych] 100 - od wyslamowania row do stawku y Przed Kołem Zapłaciłem zło[tych] 100 facit Summa expensa nato złotych 604 niech to będzie grato succesori. Budynkow pięć wystawiłem Kuchnia Szpichlerz Polowe Plebanij Zewszytkiemy meblamy Pięcamy

Szczegółowy opis wszystkich budynków parafialnych, które pozostały po ks. Klimaszewskim, zamieścił w inwentarzu z przejęcia parafii

$29 \quad$ APKal, Liber Metricus Copulatorum Anno Domini Millesimo Septemgentesimo Sexagesimo Quarto Die 15 Februar. Compatarus, k. 26.

$30 \quad$ Kolejne wpisy w księdze małżeństw pochodzą z listopada 1777 r.: „15 9bris [1777] Villa Guzy. Ego qui supra Benedixi Matrimonium inter Honestos Petrum Jankowski Juvenem et Franciscam Kakarereczanka Virgině de eadem Villa Guzy praemissis 3bs bannis nulloq: reperto Canonico Impedimento Praes. Testib. Honesto. Mathia Kakareka Francisco Kakareka ac alijs fide dignis”., k. 26.

$31 \quad$ Konsekrowany przez WJ Księdza Jana Szyjkowskiego biskupa synopeyskiego $w$ roku 1777, dnia piątego października, [w:] ADE, nr 183, Inwentarz czyli Opis Stanu Kościoła Kalinowskiego... spisany $w R^{\underline{u}} 1804$. Inwentarz z 1808 roku błędnie podaje rok 1788 jako datę konsekracji kościoła.

32 APKal, Liber Metricus Copulatorum Anno Domini Millesimo Septemgentesimo Sexagesimo Quarto Die 15 Februar. Compatarus, k. 25v-26. Por. M. Wróbel, Parafia w Kalinówce Kościelnej, s. 251. 
w 1808 roku ks. Sz. Szyszko. Wymienia w nim jeszcze inne budynki wzniesione przez poprzednika, takie jak dom dla czeladzi z 1779 roku i dwukondygnacyjny lamus pochodzący z początku lat osiemdziesiątych XVIII stulecia ${ }^{33}$.

Ksiądz W. Klimaszewski zmarł w Kalinówce 16 lipca 1808 roku. Dotknięty paraliżem, odszedł do Pana po prawie trzech latach choroby, mając 77 lat życia i 53 kapłaństwa ${ }^{34}$. Zapewne został pochowany przy kościele.

\section{Założenie nowego cmentarza grzebalnego}

Od powstania parafii kalinowskiej do początków XIX wieku zmarłych grzebano w poświęconej ziemi na cmentarzu przykościelnym w Kalinówce i przy kościele filialnym w Brzozowej. W bezpośrednim sąsiedztwie świątyni lub pod jej podłogą grzebano kapłanów, zakonników, osoby znamienitsze, należące do stanu szlacheckiego lub zasłużone dla parafii. Obok ks. A. Świerzbińskiego, in aditu Ecclesiae proboszcz W. Klimaszewski pogrzebał podstolinę Ziemi Bielskiej Mariannę z Wyszyńskich Świerzbińską z Sikor (1774) ${ }^{35}$. Przed wejściem do kościoła pochowani zostali bernardyn brat Paweł, kwestarz z klasztoru tykocińskiego $(1777)^{36}$ oraz Benedykt Mońko, szlachcic ze wsi Czokołdy (Czekołdy) w parafii Trzcianne, który ex devotione przybył przed cudowny obraz Najświętszej Maryi Panny w Kalinówce i tu dokonał żywota (1783) ${ }^{37}$. Inny szlachcic Antoni Mońko z Sikor został pogrzebany w prawej nawie kościoła $(1795)^{38}$, również w świątyni pochowano rezydującą na plebanii Annę Tołczykową (1784) oraz ogrodnika Andrzeja Szydłowskiego, który zmarł po dziewięciu latach wiernej służby na rzecz parafii $(1784)^{39}$. Z tyłu prezbiterium pogrzebano

33 $\quad \mathrm{AAB}$, Inwentarz Kościoła Kalinowskiego po śmierci śp. WJM $x$. Walentym Klimaszewskim proboszczu i kanoniku wileńskim sporzadzony y $x$. Szymonowi Szyszko w administracye podany. 1808, s. nn. 15 8bra, k. 59v: „Dnia 16 Julii: Umarł WJX Walenty Klimaszewski Kanonik Jnf. Pro: Kali. mający lat 77, a kapłaństwa 53. Paraliżem tknięty, chorowa[ł] lat 2 i miesięcy 8".

$35 \quad$ Ibidem, k. 19.

$36 \quad$ Ibidem, k. 25.

$37 \quad$ Ibidem, k. $34 \mathrm{v}$.

$38 \quad$ Ibidem, k. 55.

39 Ibidem, k. 35v. 
Mariannę z Kostrów Waskiewiczową ze wsi Waśki $(1779)^{40}$, zaś przy krzyżu zabitego przez żołnierzy Kazimierza Kołodziejkę włościanina z Białosukni (1751) ${ }^{41}$. W bezpośrednim sąsiedztwie kościoła, 18 lutego 1763 roku, po odprawieniu uroczystego nabożeństwa, został też pogrzebany o. Andrzej Sikorski, jezuita z kolegium w Brześciu i mansjonarz derewnieński, zmarły nagle podczas wizyty u krewnych w Świerzbieniach ${ }^{42}$. Na cmentarzu przeprowadzano też ekshumacje. Dnia 24 stycznia 1788 roku proboszcz i dziekan knyszyński Wojciech Godlewski otrzymał zezwolenie Kurii Wileńskiej na przeprowadzenie ekshumacji na cmentarzu kalinowskim, mającej na celu dokładne zbadanie i ponowne pogrzebanie w miejscu świętym zwłok Jerzego Daniłowskiego ${ }^{43}$.

Wymóg zakładania cmentarzy z dala od ludzkich osiedli pojawił się na przełomie XVIII/XIX wieku i wiąże się z wprowadzeniem na terenach polskich prawa obowiązującego w państwach zaborczych. W parafiach diecezji wileńskiej, które znalazły się w zaborze pruskim i rosyjskim, powstawały one stopniowo, w miejscach wyznaczonych przez władze zaborcze ${ }^{44}$. Zakładano je poza terenem zabudowanym, w pewnej odległości od kościoła (na terenie archidiakonatu białostockiego odległość ta wynosiła zazwyczaj 0,5-2,5 km). W Kalinówce w czasach pruskich takiego cmentarza jeszcze nie było, co potwierdzają inwentarze parafialne z lat 1804 i 1808, w których wspomina się jedynie o cmentarzu przy kościele ${ }^{45}$.

Drugi cmentarz został założony i poświęcony w 1811 roku przez proboszcza Szymona Szyszkę. Pozwolenia na poświęcenie cmenta-

History of the Church rza, „w miejscu poza wsią Kalinówka” i grzebanie na nim zmarłych, udzielił w Korycinie 31 października 1811 roku archidiakon białostocki Ignacy Rakowski ${ }^{46}$. Transumpt tego dokumentu ks. Szyszko zamieścił w księdze metryk umarłych z 1809 roku. Poniżej transumptu dopisał uwagę, że cmentarz poświęcił osobiście we wspomnienie Wszystkich Wiernych Zmarłych, dnia 2 listopada 1811 roku:

\footnotetext{
$40 \quad$ Ibidem, k. 28.

$41 \quad$ Ibidem, k. 2.

$42 \quad$ Ibidem, k. 8.

$43 \quad$ Ibidem, post k. 40.
}

44 Według inwentarza w parafii Zalesie w 1820 roku cmentarz znajdował się tylko przy kościele.AAB, Inwentarze Czyli Opisania Rzymsko Katolickich Parafialnych Kościołów znajdujących się w Archi Dyakonacie Białostockim... utożone i Roku 1820 podane, s. 261.

$45 \quad$ M. Wróbel, Parafia w Kalinówce Kościelnej, s. 256-257.

46 Ks. Ignacy Rakowski od 1785 roku był przez kilka lat komendarzem w parafii Kalinówka. 
Na mocy władzy Jego Cesarskiego Majestatu Aleksandra II Cesarza i Autokraty całej Rosji etc etc Pana Naszego Najmiłościwszego Stanisław Siestrzencewicz Bohusz Kościołów katolickich w Rosji jedyny metropolita biskup mohylewski, rycerz Zakonu Św. Andrzeja Apostoła i wielu innych Wielebnemu Szymonowi Szyszko Administratorowi kalinowskiemu pozdrowienie w Panu Powiadomiono mnie, że zgodnie z rozporządzeniami Jego Cesarskiej Mości w miejscu poza wsią Kalinówka powstał cmentarz, by grzebać ciała wiernych zmarłych w oddaleniu od kościoła parafialnego kalinowskiego. Udzielam ci z zachowaniem rytu Świętej Matki Kościoła władzy do poświęcenia wspomnianego cmentarza zgodnie z rytem rzymskim, [i pozwalam] by grzebano tam ciała wiernych zmarłych w Panu.

Korycin, 31 października 1811 r. Ignacy Rakowski Archidiakon Rzymskiego Katolickiego Kościoła Okręgu Białostockiego przez Stolicę Metropolitalną ustanowiony.

Poświęciłem nowy cmentarz we wspomnienie Wszystkich Wiernych

Zmarłych

2 listopada $1811 \mathrm{r}$.

Szyszko ${ }^{47}$.

Po poświęceniu, cmentarz stał się zwyczajnym miejscem grzebania parafian. Pierwszy, odnotowany w księgach parafialnych pochówek na nowym cmentarzu, nosi datę 9 listopada 1811 roku $^{48}$.

Cmentarz usytuowany został w kierunku północnym od wsi Kalinówka Kościelna, w odległości około pół kilometra od kościoła. Początkowo nie miał ogrodzenia. Nie wspomina się o nim w opisie

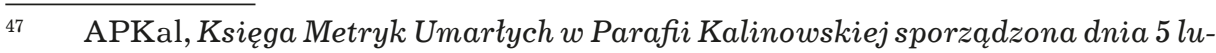
tego $1809^{g o}$ R., k. nn.: In Imperio Suae Imperatoriae Majestatis ALEXANDRI II Imperatoris at Autocratoris Totius Rossiae

ettc ettc ettc Domini Nostri Clementissimi Stanislaus Siestrzencewicz Bohusz Ecclesiarum [Ro]mano Catholicarum in Rossia Unicus Metropolitanus []chi Episcopus Mohileviensis Eques Ordinis S: Andreae Apostoli et aliorum multorum. Admodum Rendo Dno Simoni Szyszko Administratori Kalinoviensi Salutem in Domino Denuntiatum nobis est Officio Nostro quod juxta Mandata Supremis Regiminis Suae Imperatoriae Majestatis Coemeterium ad Sepelienda Corpora Defunctorum Separatim ab Ecclesia P[arochiali Kalinoviensi in loco remoto ab oppido Kalinowka Erectum, Proinde Nos hoc observando Ritum Sanctae Matris E[ccle-] siae] Dominationi Tuae damus Facultatem praedictum Coeme[ter]um] forma in Rituali Romano praescripta Benedicendi ibi[que Cor]pora Fidelium in Domino Defunctorum Sepeliendi In ?Tuam Fidem ettc Praesentes manuet Sigillo Officii Nostri[?] conatus firmantur Datt in Koricin Die 31 O[cto]bris 1811 Ann[i] Archidiaconus Romano: Catholicar[um] Ecclesiar[um] Circuli Bialostocen. in Sede Metropolitana Constitutus Ignatius Rakowski.

Benedixi Novum Caemetaerium in Commeratione O[mnium] Fidelium

Defunctorum die 2a N[ovem]bris 1811 anno

Szyszko

48 Szla:Jozefa Wroczyńskiego Gospodarza MatżonkaAntonina Karwo[w]skadie 99bris 1811 R. żyjaca lat 50. umarta z Kolkow-y pochowana na Nowym Cmentarzu, k. 7v. 
cmentarza z 1820 roku $^{49}$. Pierwsza wzmianka o kamiennym murze „ułożonym na mech” pochodzi z wizytacji generalnej z $1828 \mathrm{roku}^{50}$. Ponieważ w opisaniach parafii z 1820 roku skrupulatnie odnotowywano, czy cmentarze są ogrodzone i jakiego rodzaju posiadają ogrodzenie, brak takiej informacji przy opisie cmentarza w Kalinówce wskazuje, że ogrodzenie zostało wzniesione pomiędzy rokiem 1820 a $1828^{51}$.

Prace przy cmentarzu kontynuował ks. Mateusz Babecki, który zarządzał parafią kalinowską w latach 1835-1877. Jak informują dwie żelazne tablice wmurowane w ścianę bramy wejściowej obecnego cmentarza, bramę tę pobudował proboszcz Babecki po części z własnych funduszy ${ }^{52}$, a ponadto w 1848 roku zatroszczył się o postawienie (nowego?) muru cmentarnego ${ }^{53}$.

Nowy cmentarz parafialny był skromną wiejską nekropolią, założoną na planie zbliżonym do kwadratu o wymiarach 51 na 46 metrów, nie posiadał kaplicy ani „godnych uwagi sklepów, nagrobków i napisów”54. Na tym cmentarzu w 1877 roku został pochowany ks. Babecki, niedaleko od założyciela nekropolii ks. Szyszki, który zmarł w 1868 roku. Żeliwne nagrobki obu duszpasterzy zachowały się po dziś dzień.

Tytułem podsumowania należy zaznaczyć, że przytoczone w artykule przykłady troski proboszczów kalinowskich ofabrica ecclesiae kalinoviensis - budowa kościoła, plebanii i innych obiektów plebańskich, konsekracja świątyni oraz założenie nowego cmentarza grzebalnego - świadczą o parafii skromnie uposażonej, ale należycie zarządzanej przez gorliwych duszpasterzy, którzy w oparciu o dochody z beneficjum i dziesięcin, potrafili zapewnić warunki dla prawidłowego funk-

History of the Church cjonowania duszpasterstwa, ukierunkowanego na zbawienie dusz.

$49 \mathrm{AAB}$, Inwentarze Czyli Opisania... Roku 1820 podane: „Cmentarzodlegtyodkościoła 1/2 wiorsty, na którym chowaja się zmartych ciała. Kaplicy żadney niema”, s. 63.

50 LPAH, Wizyta Jeneralna Kościoła Parafialnego Kalinowskiego... uczyniona 1828 Roku: „Cmentarz za wsią Kalinówką od kościoła ku północy o pół wiorsty odległy - długi arszyn sześćdziesiąt pięć, szeroki siudmdziesiąt, na tym cmentarzu znajduje się krzyż drewniany ieden - murem kamiennym na mech opasany, na którym grzebią się ciała zmarłych parafian.”, k. 7v.

$51 \quad$ Por. M. Wróbel, Parafia w Kalinówce Kościelnej, s. 257.

52 Tablica wmurowana po lewej stronie od wejścia na cmentarz: CURA ET EX PARTE SUMPTU M. BABECKI K: KALINOVIENSIS.

53 Tablica wmurowana po prawej stronie od wejścia na cmentarz: HOC CAEMETERIUM MURO CIRCUMDATUM ANNO DOMINI 1848.

54 Kronika Kościoła Parafialnego w Kalinówce... 1849, [w:] G. Ryżewski, Kronika Kościoła w Kalinówce. Aneks, s. 178. 


\section{„FABRICA ECCLESIAE KALINOVIENSIS" W II POŁ. XVIII W. I NA POCZ. XIX W.}

Parafia katolicka w Kalinówce Kościelnej została założona w 1511 r. i należy do najstarszych parafii w Archidiecezji Białostockiej, będącej dawniej częścią (Archi)Diecezji Wileńskiej. W tymże roku Mikołaj Radziwiłł zbudował tu kościół, który przetrwał do czasów potopu szwedzkiego. Obecna świątynia z drzewa modrzewiowego jest trzecim z kolei kościołem pobudowanym przez ks. A. Świerzbińskiego. Dokładana data i okoliczności jej budowy nie są dokładnie znane. Świątynia została konsekrowana w 1777 r. za kolejnego proboszcza ks. W. Klimaszewskiego. On też przeprowadził szereg innych prac budowlanych i remontowych na plebanii i w gospodarstwie proboszcza. Natomiast nowy cmentarz grzebalny, położony poza Kalinówką, został założony w 1811 r. przez ks. Szymona Szyszko. Transumpt dokumentu zezwalającego na jego założenie został zamieszczony w niniejszym artykule, jak też szereg innych zapisów źródłowych, dotyczących parafii oraz kapłanów w niej posługujących.

Słowa kluczowe: parafia w Kalinówce Kościelnej, budowa kościoła, konsekracja kościoła, pożar plebanii, założenie cmentarza, parafialne księgi metrykalne, proboszczowie, komendarze.

\section{Bibliografia:}

1. Cybulko Z., Kilka uwag do dziejów kościoła kalinowskiego, „Biuletyn Konserwatorski Województwa Podlaskiego" 1999, z. 5.

2. Cybulko Z., Wartości zabytkowe kościoła parafialnego w Kalinówce Kościelnej, [w:] Parafia w Kalinówce Kościelnej 1511-2011. Pięć wieków historii, A. Szot red., Białystok - Kalinówka Kościelna 2011.

3. Kalisz A., Kalinówka Kościelna. Zespót kościoła parafialnego pw. św. Anny, Dokumentacja historyczno-architektoniczna, PKZ, O/Białystok 1980.

4. Krahel T., Zarys dziejów parafii w Kalinówce Kościelnej, [w:] Parafia w Kalinówce Kościelnej 1511-2011. Pięć wieków historii, A. Szot red., Białystok - Kalinówka Kościelna 2011.

5. Kurczewski J., Biskupstwo wileńskie, Wilno 1912.

6. Niewiński S., Juchnowiec. Dzieje parafii, Juchnowiec Kościelny 2017.

7. Ryżewski G., Kronika kościoła w Kalinówce z 1851 r., [w:] Parafia w Kalinówce Kościelnej 1511-2011. Pięć wieków historii, A. Szot red., Białystok - Kalinówka Kościelna 2011.

8. Słownik geograficzny Królestwa Polskiego i innych krajów słowiańskich, F. Sulimierski, B. Chlebowski, Wł. Walewski red., t. 3, Warszawa 1882.

9. Wróbel M., Parafia w Kalinówce Kościelnej w latach 1795-1914 w świetle działalności jej duszpasterzy, [w:] A. Szot red., Parafia w Kalinówce Kościelnej 1511-2011. Pięć wieków historii, Białystok - Kalinówka Kościelna 2011.

10. Wróbel W., Kościót parafialny $w$ Kalinówce Kościelnej i jego wyposażenie $w$ świetle inwentarza z 1620 R., [w:] Parafia w Kalinówce Kościelnej 
1511-2011. Pięć wieków historii, A. Szot red., Białystok - Kalinówka Kościelna 2011.

11. Wrzeszcz M., Kalinówka Kościelna, [w:] Encyklopedia Katolicka, t. 8, Lublin 2000.

12. Wykaz księży proboszczów parafii Kalinówka Kościelna, [w:] Parafia w Kalinówce Kościelnej 1511-2011. Pięć wieków historii, A. Szot red., Białystok - Kalinówka Kościelna 2011.

\section{Źródła archiwalne:}

1. Archiwum Archidiecezjalne w Białymstoku (AAB), Akta kościoła kalinowskiego od roku 1817oㅡ dla dobra przez ks. Szyszkę erygowane i utrzymane.

2. AAB, Inventarium Ecclesiae Kalinoviensis Post Fata Illustris Domini Adami Swierzbinski Canonici Livoniensis Parochi Kalinoviensis Conscriptum ac Illustri Domino Valentino Klimaszewski circa introductionem per me infra scriptum die 24 maj 1774 Traditum.

3. AAB, Inwentarz Kościoła Kalinowskiego po śmierci śp. WJM $x$. Walentym Klimaszewskim proboszczu i kanoniku wileńskim sporzadzony y $x$. Szymonowi Szyszko w administracye podany. 1808.

4. AAB, Inwentarze Czyli Opisania Rzymsko Katolickich Parafialnych Kościotów znajdujących się w Archi Dyakonacie Białostockim... utożone i Roku 1820 podane.

5. Archiwum Diecezjalne w Łomży (ADŁ), nr 183: Inwentarz czyli Opis Stanu Kościoła Kalinowskiego w Dekanacie Knyszyńskim ze wszystkiemi prznależytościami podtug Erekcyow Fundoszowych spisany $w R^{\underline{u}} 1804$.

6. Archiwum Parafii Kalinówka Kościelna (APKal), Księga Metryk Umartych $w$ Parafii Kalinowskiej sporzadzona dnia 5 lutego $1809^{g o} R$.

7. APKal, Liber Metrices Baptisatorum et Copulatorum Ecclesiae Parochialis Kalinoviensis ab 1742... 1738: Liber Metricaru' Copulatoru' Ecclesiae Kali-

History of the Church noviensis per me Mathaeu' Antonium Perkowski Parochum Kalinoviensem procuratus proprio Su'ptu Anno Dni 1738 Die 23. 8bris.

8. APKal, Liber Metrices Ecclesiae Parochialis Kalinoviensis Brzozoviensisq. tam ex una Parte Baptisatorum quam ex Altera Parte Conjugatorum (...) Per me Adamum Swierzbinski Canonicum Livoniensem Kalivoviensem Brzozoviensemq. Parochum Anno Domini 1764 Die 15 Februarij Comparatus.

9. APKal, Liber Parochianorum Kalinoviensium In Domino Mortuorum et circa Ecclesiam parochialem kalinoviensem Sepultorum post obtentum Rectoratum praedictae Ecclesiae Per me Joannem Antonium Czaczkowski Kalinoviensem et Brzozoviensem modernum Parochum Anno Domini 1749. Scribi Inceptus et Comparatus.

10. APKal, Metryki Umartych Parafii Kalinowskiej Sporzadzone w Roku 1797 Dnia 15 8bra.

11. Litewskie Państwowe Archiwum Historyczne w Wilnie (LPAH), f. 694, op. 1, d. 3747), Wizyta Jeneralna Kościota Parafialnego Kalinowskiego... uczyniona 1828 Roku Miesiaca Listopada. 